\title{
Prosociality and the Uptake of COVID-19 Contact Tracing Apps: Survey Analysis of Intergenerational Differences in Japan
}

Masahiro Shoji ${ }^{1 *}, \mathrm{PhD}$; Asei Ito ${ }^{1 *}, \mathrm{PhD}$; Susumu Cato ${ }^{1 *}, \mathrm{PhD}$; Takashi Iida ${ }^{1 *}$, LLM; Kenji Ishida ${ }^{1 *}$, PhD; Hiroto Katsumata $^{2^{*}}, \mathrm{PhD}$; Kenneth Mori McElwain ${ }^{1 *}, \mathrm{PhD}$

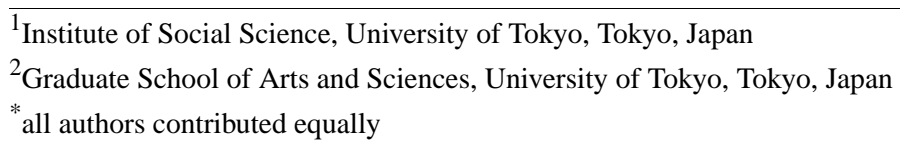

Corresponding Author:

Masahiro Shoji, PhD

Institute of Social Science

University of Tokyo

7-3-1 Hongo, Bunkyo-ku

Tokyo, 113-0033

Japan

Phone: 81358414927

Email: shoji@iss.u-tokyo.ac.jp

\section{Abstract}

Background: To control the COVID-19 pandemic, it is essential to trace and contain infection chains; for this reason, policymakers have endorsed the usage of contact tracing apps. To date, over 50 countries have released such apps officially or semiofficially, but those that rely on citizens' voluntary uptake suffer from low adoption rates, reducing their effectiveness. Early studies suggest that the low uptake is driven by citizens' concerns about security and privacy, as well as low perceptions of infection risk and benefits from the usage. However, these do not explore important generational differences in uptake decision or the association between individuals' prosociality and uptake.

Objective: The objective of our study was to examine the role of individuals' prosociality and other factors discussed in the literature, such as perceived risk and trust in government, in encouraging the usage of contact tracing apps in Japan. We paid particular attention to generational differences.

Methods: A web-based survey was conducted in Japan 6 months after the release of a government-sponsored contact tracing app. Participants were recruited from individuals aged between 20 and 69 years. Exploratory factor analyses were conducted to measure prosociality, risk perception, and trust in government. Logistic regression was used to examine the association between these factors and uptake.

Results: There was a total of 7084 respondents, and observations from 5402 respondents were used for analysis, of which 791 respondents $(14.6 \%)$ had ever used the app. Two factors of prosociality were retained: agreeableness and attachment to the community. Full-sample analysis demonstrated app uptake was determined by agreeableness, attachment to the community, concern about health risks, concern about social risks, and trust in the national government; however, important differences existed. The uptake decision of respondents aged between 20 and 39 years was attributed to their attachment to the community (odds ratio [OR] 1.28, 95\% CI 1.11-1.48). Agreeable personality (OR 1.18, 95\% CI 1.02-1.35), concern about social risk (OR $1.17,95 \%$ CI 1.02-1.35), and trust in national government (OR 1.16, 95\% CI 1.05-1.28) were key determinants for those aged between 40 and 59 years. For those aged over 60 years, concerns about health risks determined the uptake decision (OR 1.49, 95\% CI 1.24-1.80).

Conclusions: Policymakers should implement different interventions for each generation to increase the adoption rate of contact tracing apps. It may be effective to inform older adults about the health benefits of the apps. For middle-age adults, it is important to mitigate concerns about security and privacy issues, and for younger generations, it is necessary to boost their attachment to their community by utilizing social media and other web-based network tools.

(JMIR Mhealth Uhealth 2021;9(8):e29923) doi: 10.2196/29923 


\section{KEYWORDS}

COVID-19; contact tracing app; place attachment; place identity; contact tracing; pandemic; mHealth; health policy

\section{Introduction}

\section{Background}

The COVID-19 pandemic has caused immense human and socioeconomic harm worldwide [1,2]. To contain the pandemic, it is essential to track infection chains and prevent further spread of infections. Traditionally, this was performed manually through call centers, but given the progress of digital technology and mobile phones, policymakers have increasingly endorsed the usage of contact tracing apps [3]. These apps send users a warning message when other users with whom they have been in close contact are confirmed to be infected. As of January 2021 , over 50 nations have released such apps officially or semiofficially [4], and policymakers expected this new technology to play a pivotal role in controlling the infection spread [5].

However, to date, the apps have not been as successful as originally expected in many countries. According to an early simulation, a $56 \%$ adoption rate was necessary to contain the virus effectively [6]. The governments of Singapore and Qatar required that citizens download contact tracing apps and achieved over $80 \%$ adoption. By contrast, many countries that have relied on citizens' voluntary uptake have failed to reach the required level of uptake. In the United Kingdom, only $28.5 \%$ of citizens installed the app, and in Germany, the download and installation rate was as low as $21.7 \%$ at the end of January 2021 [4].

Studies [7-11] have suggested that low uptake rates were driven by citizens' concerns about security and privacy, poor trust in government, low perceived infection risk, and low perceived benefit from usage; however, 2 issues remained unaddressed. First, generational differences in uptake decisions were largely unexplored. This issue is crucial given differences in the health impact of infections and in familiarity with mobile apps across age groups. Second, little attention was paid to an important characteristic of the apps-the apps prevent users from spreading the virus but do not protect users themselves from infections. Therefore, motives for using the app could vary among individuals by their prosociality or their willingness to engage in prosocial behavior. Prosocial behavior is "a broad category of actions that are defined by society as generally beneficial to other people and to the ongoing political system [12]." The prosocial feature of contact tracing apps is crucial in the context of the COVID-19 pandemic, because early studies [13] warned that economic losses and lack of social interactions due to mandatory or voluntary social distancing may aggravate individuals' antisocial behavior. It is also important to discuss whether disaster-prevention infrastructure and community play complementary or substitute roles in disaster preparedness, response, and resilience; these are major issues in disaster research [14].

\section{Aims}

The goal of this study was to examine the role of individuals' prosociality and other factors discussed in the literature, such as perceived risk and trust in government, in encouraging the usage of contact tracing apps in Japan. We paid particular attention to generational differences. Uncovering generational differences will enable policymakers to tailor interventions to each age group. This is relevant in countries where specific age ranges are exposed to higher infection risks than others. In Japan, 744,953 people were confirmed to be infected, of which $37 \%$ were between 20 and 39 years of age (as of June 2, 2021) [15]. Controlling the spread of infection among this generation is especially important.

\section{Methods}

\section{Survey Design}

We conducted an original nationwide web-based survey in Japan, which was designed to collect data from approximately 7000 people aged between 20 and 69 years. In the sampling process, 68,480 people were selected from registrants of a large (4.65 million registrants) survey company in Japan (Cross Marketing Inc). Registrants were randomly sampled with stratification with respect to gender ( 2 categories), age (10 categories with 5-year ranges), and location of residence (10 categories: Hokkaido, Tohoku, Minami-Kanto, Kita-Kanto and Koshin, Hokuriku, Tokai, Kinki, Chugoku, Shikoku, and Kyushu), so that the expected distribution of these characteristics was comparable to that of the Japanese population.

The Japanese government released its official mobile app-the COVID-19 Contact Confirming App (COCOA) —in June 2020. The invitation for the survey was sent to 68,480 members by email on December 18, 2020, 6 months after the release of COCOA. Participants were informed that they would receive shopping tokens as a financial incentive and that the survey would be closed once the required sample size was obtained. The survey was closed on December 21, by which time 9369 individuals read the informed consent on the survey website, 7997 agreed to participate, and 7084 completed the survey (response rate among those who visited the website: $75.6 \%$ ). The questionnaire collected information about respondents, including protective measures taken against COVID-19, perceived risks from COVID-19 pandemic, the usage of mobile apps, personality traits, political beliefs and ideology, physical and mental health, demographic characteristics, and socioeconomic characteristics. There were 36 questions and the survey website was designed using Qualtrics (Qualtrics XM). We obtained research ethics approval for this project from the institutional review board of the Institute of Social Science, the University of Tokyo. 


\section{Measures}

\section{Uptake of Contact Tracing App}

The app used a decentralized data privacy approach, which was among the 3 main design types (centralized, decentralized, and hybrid ) for contact tracing apps worldwide [16,17]. Using Bluetooth sensors inside mobile phones, COCOA detects and records the app ID of other users who remain within 1 meter for more than 15 minutes [18]. The contact information is encrypted to maintain anonymity, and it is stored for 14 days only in the user's mobile phone before being automatically destroyed. This design secures users' privacy while tracing infection chains. In the event that a user is confirmed to be infected with COVID-19 and they voluntarily report it via the app, other users with whom they have been in close contact in the preceding 14 days receive a warning message. Individuals who receive a warning message can receive reverse-transcription polymerase chain reaction tests for free. Similar to apps in other countries, COCOA requires population adoption rates as high as $60 \%$ to contain the virus effectively. However, it is difficult to achieve this level through voluntary, individual compliance alone. As of December 28, 2020, the adoption rate was only $17.6 \%$ (22.5 million downloads) [19].

In this study, our dependent variable was a binary indicator (equal to 1 if the respondent had ever downloaded COCOA since its release in June 2020 and equal to 0 otherwise).

\section{Prosociality}

Individuals' motives for prosocial behavior have long been debated in various disciplines, including economics, sociology, and psychology. While different researchers categorize such motives in different manners, we draw on economics and psychology and classify them into intrinsic motivation, extrinsic incentive, and relationship with their community [20-22].

First, the literature on intrinsic motivation shows that individuals' prosocial behavior, such as volunteering, is attributed to their prosocial personality or preference, such as altruism, fairness, guilt, and empathy [23,24]. This is consistent with research from personality psychology on the agreeable personality trait, which includes facets of altruism and empathy $[25,26]$.

Second, regarding the extrinsic incentive, people whose behavior deviates from the social norms of their community may experience nonmonetary punishment from others, such as disapproval, stigma, and negative social image [27]. Therefore, those who care about such punishments have incentives to behave prosocially. One may be concerned whether this motive is effective during the COVID-19 pandemic, given that research in criminology notes the aggravation of antisocial behavior in socially disorganized communities [28]. Although increases in crime in disaster-affected areas are a common problem worldwide [29,30], some have suggested the critical role of social norms and social images in Japanese disaster-affected communities [31]. Furthermore, social sanctions against antisocial behavior may be even stronger during the COVID-19 pandemic because of increased infection risk to community members. Hence, this motive may remain important in encouraging the uptake of contact tracing apps.
A third factor that motivates prosocial behavior is individuals' relationships with community members. Experimental studies [32-34] show that participants are more likely to be altruistic and cooperative when they play experimental games with in-group members, such as those sharing the same ethnicity and neighborhood. Empirical studies [35] also show that people are more likely to contribute to their community when its members are homogeneous in terms of ethnic and religious backgrounds, suggesting the importance of attachment to and identification with the community in encouraging prosocial behavior. These arguments are also in line with research on place identity [36], community attachment [37], and sense of community [38]. While there are some distinctions, many agree on the importance of emotional attachment to the community in motivating prosocial behavior $[39,40]$.

To capture these motives for prosociality, we used 6 items. Items 1 and 2 (Table 1) have been proposed and validated [41] to elicit agreeableness in the Big 5 personality traits. These items were measured on a 7-point Likert scale, and a lower score on item 1 and a higher score on item 2 indicated higher agreeableness. Items 3 and 4 captured respondents' sensitivity to social norms. These were drawn from the World Values Survey [42] but were modified for ease of visibility on the web-based survey platform. These items were measured on a 5-point Likert scale. Items 5 and 6 measured respondents' attachment to their community. Item 5 demonstrated the highest factor loadings of 6 items in principal component analysis to capture place identity [43]. Other studies [44,45] also employ this item to measure place identity. Although this item measures individuals' place identity to their neighborhood, it may be the case that strength of identity varies with definition of place [46]; therefore, we added item 6 to capture identity as Japanese citizens. These items were measured on a 4-point Likert scale. Responses in which option 99 (ie, "do not want to answer") had been selected were dropped from the estimations. In line with methods used in earlier work [41], items 1 and 2 did not include option 99, but we allowed respondents to move to the next question without answering these questions.

\section{Risk Perception}

According to Protection Motivation Theory [47], risk perception describes how a person assesses a threat's probability and potential damage; it is determined based on perceived probability, perceived severity, fear, and the perceived reward for a maladaptive response. It has been suggested that variation in risk perception contributes to differences in behavioral responses to the COVID-19 pandemic in Japan [48].

We measured these characteristics with items 7 to 11 (Table 1). The first 4 questions measured perceived probability and severity of COVID-19 in terms of different domains, such as infection risk and job security. The fifth question is frequently used in the literature to measure individuals' willingness to take risks and draws from earlier work in the United States [49,50]. We used it as a proxy for fear. All items were measured with a 5-point Likert scale, where higher scores indicated higher risk perception. 
Table 1. Description of items.

\begin{tabular}{|c|c|c|}
\hline \multicolumn{2}{|l|}{ Items } & Rating, mean (SD) \\
\hline \multicolumn{3}{|c|}{ Prosociality } \\
\hline 1 & I see myself as critical, quarrelsome. ${ }^{\mathrm{a}}$ & $2.99(1.41)$ \\
\hline 2 & I see myself as sympathetic, warm. ${ }^{\text {a }}$ & $4.44(1.27)$ \\
\hline 3 & It is important to avoid doing anything people would say is wrong. ${ }^{b}$ & $2.96(0.99)$ \\
\hline 4 & It is important to behave properly. ${ }^{\text {b }}$ & $3.60(0.94)$ \\
\hline 5 & I am very attached to my neighborhood. ${ }^{\mathrm{c}}$ & $2.80(0.84)$ \\
\hline 6 & I am proud of being a Japanese citizen. ${ }^{c}$ & $2.91(0.81)$ \\
\hline \multicolumn{3}{|c|}{ Risk perception } \\
\hline 7 & I am concerned about the impact of COVID-19 on my infection risk. ${ }^{\text {b }}$ & $3.78(1.02)$ \\
\hline 8 & I am concerned about the impact of COVID-19 on serious symptoms. ${ }^{\text {b }}$ & $3.31(1.10)$ \\
\hline 9 & I am concerned about the impact of COVID-19 on my job. ${ }^{\text {b }}$ & $3.31(1.20)$ \\
\hline 10 & I am concerned about the impact of COVID-19 on my interpersonal relationships. ${ }^{b}$ & $3.21(1.14)$ \\
\hline 11 & $\begin{array}{l}\text { Which of these sayings characterizes you better? (A) Nothing ventured, nothing gained (B) A wise man never } \\
\text { courts danger }\end{array}$ & $3.60(1.23)$ \\
\hline \multicolumn{3}{|c|}{ Trust in government } \\
\hline 12 & Do you trust the government? ${ }^{\mathrm{c}}$ & $1.99(0.79)$ \\
\hline 13 & Do you evaluate the current prime minister positively? ${ }^{\text {b }}$ & $2.58(1.20)$ \\
\hline 14 & Do you evaluate the previous prime minister positively? ${ }^{\mathrm{b}}$ & $2.29(1.08)$ \\
\hline 15 & Do you evaluate the current governor of home prefecture positively? & $2.94(1.09)$ \\
\hline
\end{tabular}

${ }^{a}$ Response options were (1) disagree strongly, (2) disagree moderately, (3) disagree a little, (4) neither agree nor disagree, (5) agree a little, (6) agree moderately, or (7) agree strongly.

${ }^{\mathrm{b}}$ Response options were (1) no, (2) weakly no, (3) neutral, (4) weakly yes, (5) yes, or (99) do not want to answer.

${ }^{\mathrm{c}}$ Response options were (1) no, (2) weakly no, (3) weakly yes, (4) yes, or (99) do not want to answer.

${ }^{\mathrm{d}}$ Response options were (1) B, (2) lean B, (3) neutral, (4) lean A, (5) A, or (99) do not want to answer.

\section{Trust in Government}

Studies $[9,11]$ have noted that concerns about security and privacy are major obstacles to the adoption of contact tracing apps, given that such apps use GPS, Bluetooth, or other technologies that can reveal sensitive personal information. It is, therefore, unsurprising that individuals with low trust in the government (institutional trust) are less likely to use the apps $[8,9]$. Although the Japanese app prioritizes the protection of users' privacy from the government and corporations [51], there is anecdotal evidence that such concerns exist about the COCOA app [52].

Our survey included 4 questions to measure respondents' trust in government. Item 12 asked the extent to which respondents trust the Japanese government; responses were measured with a 4-point Likert scale. This is frequently used in the literature [7,53]. Items 13, 14, and 15 asked respondents to evaluate the performance of the current prime minister, previous prime minister, and the governor of their home prefecture, respectively, on a 5-point Likert scale.

\section{Statistical Analysis}

For data reduction, we performed 3 sets of exploratory factor analyses separately, using the items for prosociality, risk perception, and trust in government. Specifically, we used iterated principal factor extraction and promax rotation to obtain simple factor structures. The number of factors was determined based on the eigenvalue and the scree plot. To label the resulting factors, we used items with factor loadings above 0.4. Regression was used to calculate the factor score, and the factor score was standardized (mean 0, SD 1).

Understanding effective policy interventions to facilitate the uptake of contact tracing apps requires the analysis of both the determinants and consequences of these estimated factors. Therefore, we conducted ordinary least squares regression to examine socioeconomic and demographic predictors. Specifically, respondents' estimated factor scores were regressed on their age groups (20-29 years [baseline], 30-39 years, 40-49 years, 50-59 years, and 60-69 years), gender, whether the respondent completed university, whether the respondent engaged in a regular job (eg, self-employed, corporate executive, or full-time employee), marital status, whether they lived with 
a child, whether they lived with a parent, and prefecture dummy variables. Japan has 47 prefectures, which are subnational units of government. The prefecture dummy variables were included to control for prefecture-level characteristics, such as the severity of infection spread. Standard errors were clustered at the prefecture level.

Subsequently, multivariate logistic regression was conducted to examine the association between the usage of COCOA and estimated factors for prosociality, risk perception, and trust in the government. The estimation model also included the control variables (respondents' age, gender, completed university, a regular job, marital status, cohabitation with a child, cohabitation with a parent, and prefecture dummies). Results from regression analyses were reported as odds ratio (OR) with $95 \%$ CI. In addition to the full-sample model, we conducted subsample estimations by respondent age groups ( 3 categories: $20-39$ years, 40-59 years, and 60-69 years).

Given that the empirical results depend on the method used to quantify these factors, for robustness, we used 2 alternative approaches for the logistic regression models. First, for each factor, we chose the item with the highest factor loading and used the responses to these items as independent variables instead of factor scores. Second, using only the items whose factor loadings were higher than 0.4 in the factor analysis, we conducted principal component analysis with 1 component. Subsequently, we estimated the predicted scores and used them in the logistic regression. All analyses were performed in Stata (version 14; StataCorp LLC).

\section{Results}

\section{Sample Characteristics}

Among the 7084 respondents who completed the survey, we discarded the responses of those who finished the survey too quickly (less than 5 minutes) or too slowly (more than 30 minutes) to control for survey quality. Our final sample size was 5402, of which 791 respondents $(14.6 \%$ ) had used COCOA. Males, university graduates, and those with regular jobs were more likely to use COCOA (Table 2). Differences were not significant for age $(P=.09)$, marital status $(P=.39)$, or household structure (living with child: $P=.15$; living with parent: $P=.19$ ).

Table 2. Characteristics of the study sample grouped by COCOA usage.

\begin{tabular}{|c|c|c|c|c|}
\hline Characteristic & All $(\mathrm{N}=5402)$ & Users $(n=791)$ & Non-users $(\mathrm{n}=4611)$ & $P$ value \\
\hline Age (years), mean (SD) & $45.94(13.28)$ & $46.68(13.44)$ & $45.81(13.25)$ & .09 \\
\hline Gender, n (\%) & & & & .006 \\
\hline Female & $2544(47.1)$ & $337(42.6)$ & $2207(47.9)$ & \\
\hline Male & $2858(52.9)$ & $454(57.4)$ & $2404(52.1)$ & \\
\hline Education, $\mathbf{n}(\%)$ & & & & $<.001$ \\
\hline Completed university & $2775(51.4)$ & $468(59.2)$ & $2307(50.0)$ & \\
\hline Did not complete university & $2627(48.6)$ & $323(40.8)$ & $2304(50.0)$ & \\
\hline Employment, n (\%) & & & & $<.001$ \\
\hline Regular job & $2725(50.4)$ & $454(57.4)$ & $2271(49.3)$ & \\
\hline Nonregular job & $1130(20.9)$ & $152(19.2)$ & $978(21.2)$ & \\
\hline Not working & $1494(27.7)$ & $178(22.5)$ & $1316(28.5)$ & \\
\hline Other & $53(1.0)$ & $7(0.9)$ & $46(1.0)$ & \\
\hline Marital status, n (\%) & & & & .39 \\
\hline Married & $3031(56.1)$ & $455(57.5)$ & $2576(55.9)$ & \\
\hline Unmarried & $1988(36.8)$ & $280(35.4)$ & $1708(37.1)$ & \\
\hline Other & $377(7.0)$ & $56(7.1)$ & $321(7.0)$ & \\
\hline Living with parent, $n(\%)$ & & & & .19 \\
\hline Yes & $1491(27.6)$ & $203(25.7)$ & $1288(27.9)$ & \\
\hline No & $3911(72.4)$ & $588(74.3)$ & $3323(72.1)$ & \\
\hline Living with child, n (\%) & & & & .15 \\
\hline Yes & $1798(33.3)$ & $281(35.5)$ & $1517(32.9)$ & \\
\hline No & $3604(66.7)$ & $510(64.5)$ & $3094(67.1)$ & \\
\hline
\end{tabular}

To evaluate the national representativeness of our respondents, we compared the characteristics of our respondents with those of smartphone owners in Japan from the Communications Usage Trend Survey [54], a nationally representative survey conducted by the government in 2019. This survey collected information about the usage of Information and Communication Technologies among Japanese citizens [54]. Since this study examines uptake decisions for a mobile app, those who do not 
have access to internet or smartphone were not of interest. Our sample of respondents was representative of smartphone owners in Japan (Table S1 in Multimedia Appendix 1).

\section{Factor Analysis}

We began by conducting a Barlett test of sphericity, which found significant correlations between items $(P<.001)$, suggesting the adequacy of using factor analysis. Regarding prosociality, although only the first factor demonstrated an eigenvalue greater than 1 (eigenvalue 1.52), we also retained the second factor (eigenvalue 0.75 ) based on the scree plot (Table 3). These factors explained $63.1 \%$ and $31.0 \%$ of the variance in the data. After promax rotation, items 1 and 2 demonstrated high factor loadings in the first factor, which we labeled Agreeableness. The second factor was characterized by high factor loadings of items 5 and 6; therefore, it was labeled Attachment to the community.

We extracted 2 factors for risk perception (Table 4). The first factor (eigenvalue 1.80) demonstrated high factor loadings for items 7 and 8; therefore, it was labeled Concern about health risk. Likewise, the second factor (eigenvalue 0.47), which demonstrated high factor loadings for items 9 and 10, was labeled Concern about social risk. These factors accounted for $74.1 \%$ and $19.3 \%$ of the variance.

Finally, we extracted 1 factor related to trust in government (eigenvalue 1.89). Given the high factor loadings of items 12, 13 , and 14 and the low factor loading of item 15, it was labeled Trust in national government. This accounted for $98.6 \%$ of total variance (Table 5).

Table 3. Prosociality factor loadings.

\begin{tabular}{lll}
\hline Prosociality items & Agreeableness & Attachment to the community \\
\hline I see myself as critical, quarrelsome. & -0.5488 & -0.0278 \\
I see myself as sympathetic, warm. & 0.5365 & 0.0007 \\
I am very attached to my neighborhood. & -0.0046 & 0.7129 \\
I am proud of being a Japanese citizen. & 0.0155 & 0.7043 \\
It is important to avoid doing anything people would say is wrong. & 0.0167 & -0.0052 \\
It is important to behave properly. & 0.2500 & 0.0071 \\
\hline
\end{tabular}

Table 4. Risk perception factor loadings.

\begin{tabular}{|c|c|c|}
\hline Risk perception items & Concern about health risk & Concern about social risk \\
\hline I am concerned about the impact of COVID-19 on serious symptoms. & 0.8329 & -0.0113 \\
\hline I am concerned about the impact of COVID-19 on my infection risk. & 0.6532 & 0.0825 \\
\hline I am concerned about the impact of COVID-19 on my interpersonal relationships. & 0.0633 & 0.6817 \\
\hline I am concerned about the impact of COVID-19 on my job. & -0.0139 & 0.6371 \\
\hline
\end{tabular}

Table 5. Trust in government factor loadings.

\begin{tabular}{ll}
\hline Trust in government items & Trust in national government \\
\hline Do you evaluate the current prime minister positively? & 0.7853 \\
Do you evaluate the previous prime minister positively? & 0.7695 \\
Do you trust the government? & 0.4557 \\
Do you evaluate the current governor of home prefecture positively? & 0.2325 \\
\hline
\end{tabular}

\section{Predictors of Factor Scores}

Factor score variables were standardized. Older and married respondents had higher agreeableness and attachment to the community (Table 6). In addition, female and university-educated respondents demonstrated higher agreeableness scores, and respondents cohabiting with a parent or a child exhibited higher attachment to the community. The factors for risk perception were higher for female respondents and respondents cohabiting with a parent. Concern about health risk increased with age and was higher for married persons, while concern about social risk was higher for respondents with higher educational attainment, with a regular job, and who cohabited with a child. Finally, trust in national government was negatively associated with age and positively associated with cohabiting with a child. 
Table 6. Predictors of factor scores.

\begin{tabular}{|c|c|c|c|c|c|}
\hline \multirow[t]{2}{*}{ Variable } & \multicolumn{5}{|c|}{ Ordinary least square coefficients $(95 \% \mathrm{CI})$} \\
\hline & Agreeableness & $\begin{array}{l}\text { Attachment to the com- } \\
\text { munity }\end{array}$ & $\begin{array}{l}\text { Concern about health } \\
\text { risk }\end{array}$ & $\begin{array}{l}\text { Concern about social } \\
\text { risk }\end{array}$ & $\begin{array}{l}\text { Trust in national govern- } \\
\text { ment }\end{array}$ \\
\hline Aged 30 to 39 years & $\begin{array}{l}-0.132 * *(-0.210 \text { to } \\
-0.055)\end{array}$ & $\begin{array}{l}-0.096(-0.217 \text { to } \\
0.024)\end{array}$ & $0.04(-0.052$ to 0.126$)$ & $\begin{array}{l}-0.087(-0.182 \text { to } \\
0.007)\end{array}$ & $\begin{array}{l}-0.194 * * *(-0.264 \text { to } \\
-0.123)\end{array}$ \\
\hline Aged 40 to 49 years & $\begin{array}{l}-0.062(-0.137 \text { to } \\
0.012)\end{array}$ & $\begin{array}{l}-0.005(-0.126 \text { to } \\
0.116)\end{array}$ & $\begin{array}{l}0.130 * *(0.052 \text { to } \\
0.207)\end{array}$ & $\begin{array}{l}-0.009(-0.108 \text { to } \\
0.091)\end{array}$ & $\begin{array}{l}-0.300 * * *(-0.378 \text { to } \\
-0.221)\end{array}$ \\
\hline Aged 50 to 59 years & $\begin{array}{l}0.103 * *(0.027 \text { to } \\
0.179)\end{array}$ & $\begin{array}{l}0.190 * * *(0.088 \text { to } \\
0.293)\end{array}$ & $\begin{array}{l}0.258 * * *(0.172 \text { to } \\
0.344)\end{array}$ & $\begin{array}{l}-0.017(-0.111 \text { to } \\
0.076)\end{array}$ & $\begin{array}{l}-0.312 * * *(-0.398 \text { to } \\
-0.226)\end{array}$ \\
\hline Aged 60 to 69 years & $\begin{array}{l}0.250 * * *(0.156 \text { to } \\
0.345)\end{array}$ & $\begin{array}{l}0.446 * * *(0.327 \text { to } \\
0.564)\end{array}$ & $\begin{array}{l}0.435 * * *(0.355 \text { to } \\
0.515)\end{array}$ & $\begin{array}{l}-0.074(-0.184 \text { to } \\
0.036)\end{array}$ & $\begin{array}{l}-0.401 * * *(-0.499 \text { to } \\
-0.302)\end{array}$ \\
\hline Female & $\begin{array}{l}0.177 * * *(0.129 \text { to } \\
0.226)\end{array}$ & $0.07(-0.008$ to 0.155$)$ & $\begin{array}{l}0.215 * * *(0.161 \text { to } \\
0.270)\end{array}$ & $\begin{array}{l}0.216 * * *(0.161 \text { to } \\
0.272)\end{array}$ & $0.01(-0.066$ to 0.080$)$ \\
\hline $\begin{array}{l}\text { Completed universi- } \\
\text { ty }\end{array}$ & $\begin{array}{l}0.096 * *(0.034 \text { to } \\
0.158)\end{array}$ & $0.00(-0.073$ to 0.081$)$ & $0.05(-0.001$ to 0.099$)$ & $\begin{array}{l}0.081 * *(0.029 \text { to } \\
0.132)\end{array}$ & $\begin{array}{l}-0.001(-0.059 \text { to } \\
0.057)\end{array}$ \\
\hline Regular job & $0.02(-0.040$ to 0.070$)$ & $0.05(-0.012$ to 0.112$)$ & $0.01(-0.046$ to 0.058$)$ & $\begin{array}{l}0.320 * * *(0.264 \text { to } \\
0.376)\end{array}$ & $0.06(-0.013$ to 0.125$)$ \\
\hline Married & $\begin{array}{l}0.123 * *(0.048 \text { to } \\
0.198)\end{array}$ & $\begin{array}{l}0.126 * * *(0.062 \text { to } \\
0.190)\end{array}$ & $0.092 *(0.020$ to 0.164$)$ & $0.05(-0.042$ to 0.131$)$ & $0.02(-0.044$ to 0.078$)$ \\
\hline Live with a parent & $0.03(-0.035$ to 0.092$)$ & $\begin{array}{l}0.121 * * *(0.065 \text { to } \\
0.176)\end{array}$ & $\begin{array}{l}0.127 * *(0.052 \text { to } \\
0.202)\end{array}$ & $\begin{array}{l}0.096 * *(0.028 \text { to } \\
0.164)\end{array}$ & $0.02(-0.051$ to 0.091$)$ \\
\hline Live with a child & $0.06(-0.010$ to 0.132$)$ & $\begin{array}{l}0.143 * * *(0.071 \text { to } \\
0.214)\end{array}$ & $0.04(-0.042$ to 0.124$)$ & $0.09(-0.002$ to 0.191$)$ & $\begin{array}{l}0.095 * *(0.032 \text { to } \\
0.159)\end{array}$ \\
\hline $\begin{array}{l}\text { Prefecture fixed ef- } \\
\text { fects }\end{array}$ & Yes & Yes & Yes & Yes & Yes \\
\hline
\end{tabular}

$* P<.05$.

$* * P<.01$.

$* * * P<.001$.

\section{Association With the Uptake of COCOA}

Full-sample results (Table 7) for Model 1 show that all factors significantly increased the odds of using COCOA (agreeableness: OR 1.15, 95\% CI 1.07-1.23; attachment to the community: OR $1.20,95 \%$ CI 1.07-1.35; concern about health risk: OR 1.25, 95\% CI 1.12-1.41; concern about social risk: OR $1.14,95 \%$ CI 1.04-1.24; trust in national government: OR 1.08, 95\% CI 1.00-1.17). OR magnitudes did not differ significantly across factors $\left(\chi^{2}=6.30, P=.18\right)$. Respondents' socioeconomic status characteristics, such as education and having a regular job, were positively correlated with app usage. University graduates were 1.33 times more likely to install COCOA than high school graduates were, and having a regular job increased odds by 1.25. Other demographic characteristics (gender: $P=.12$; age: $P=.25$; living with a parent: $P=.41$, living with a child: $P=.41$ ) were not correlated with app uptake. Subsample estimations for Models 2 to 4 uncovered heterogeneity in determinants across the 3 major age groups. Among respondents aged 20 to 39 years (Model 2), attachment to the community was a major determinant of uptake (OR 1.28, 95\% CI 1.11-1.48). Among respondents aged 40 to 59 years, the uptake of COCOA was attributed to respondents' high agreeableness (OR 1.18, 95\% CI 1.02-1.35), concern about social risk (OR 1.17, 95\% CI 1.02-1.35), and trust in the national government (OR 1.16, 95\% CI 1.05-1.28). For respondents aged over 60, uptake was attributed to higher concern about health risks (OR 1.49, 95\% CI 1.24-1.80).

The correlates of COCOA uptake using responses to items 1, $5,8,10$, and 13, which had the highest factor loadings for each of the factors, demonstrate robustness (Table S2 in Multimedia Appendix 1), and the association between COCOA uptake and factor scores computed with principal component analysis did not change qualitatively (Table S3 in Multimedia Appendix 1). 
Table 7. Association with the uptake of the COVID-19 Contact Confirming App.

\begin{tabular}{|c|c|c|c|c|}
\hline \multirow[t]{2}{*}{ Variable } & \multicolumn{4}{|l|}{ Odds ratio $(95 \% \mathrm{CI})$} \\
\hline & Model 1: All (n=5398) & $\begin{array}{l}\text { Model 2: Age 20-39 years } \\
(\mathrm{n}=1765)\end{array}$ & $\begin{array}{l}\text { Model 3: Age 40-59 years } \\
(\mathrm{n}=2488)\end{array}$ & $\begin{array}{l}\text { Model 4: Age 60-69 years } \\
(\mathrm{n}=982)\end{array}$ \\
\hline Agreeableness & $1.15 * * *(1.07$ to 1.23$)$ & $1.13(0.99$ to 1.30$)$ & $1.18 *(1.02$ to 1.35$)$ & $1.15(0.97$ to 1.36$)$ \\
\hline $\begin{array}{l}\text { Attachment to the communi- } \\
\text { ty }\end{array}$ & $1.20 * *(1.07$ to 1.35$)$ & $1.28 * * *(1.11$ to 1.48$)$ & $1.19(0.94$ to 1.50$)$ & $1.03(0.81$ to 1.30$)$ \\
\hline Concern about health risk & $1.25 * * *(1.12$ to 1.41$)$ & $1.15(0.94$ to 1.42$)$ & $1.20(0.97$ to 1.48$)$ & $1.49 * * *(1.24$ to 1.80$)$ \\
\hline Concern about social risk & $1.14 * *$ (1.04 to 1.24$)$ & $1.18(0.96$ to 1.45$)$ & $1.17 *(1.02$ to 1.35$)$ & $1.05(0.85$ to 1.29$)$ \\
\hline $\begin{array}{l}\text { Trust in national govern- } \\
\text { ment }\end{array}$ & $1.08 *(1.00$ to 1.17$)$ & $0.98(0.85$ to 1.14$)$ & $1.16^{* *}(1.05$ to 1.28$)$ & $1.08(0.88$ to 1.31$)$ \\
\hline Age & $1.00(1.00$ to 1.01$)$ & $0.99(0.95$ to 1.02$)$ & $1.01(0.98$ to 1.03$)$ & $1.00(0.93$ to 1.08$)$ \\
\hline Female & $0.88(0.76$ to 1.03$)$ & $0.93(0.70$ to 1.24$)$ & $0.92(0.77$ to 1.10$)$ & $0.74(0.45$ to 1.22$)$ \\
\hline Completed university & $1.33 * *(1.12$ to 1.57$)$ & $1.77 * * *$ (1.30 to 2.42$)$ & $1.19(0.95$ to 1.49$)$ & 1.07 (0.65 to 1.76$)$ \\
\hline Regular job & $1.25 * *(1.07$ to 1.47$)$ & $1.11(0.77$ to 1.60$)$ & $1.36^{*}$ (1.01 to 1.83 ) & $1.32(0.87$ to 2.00$)$ \\
\hline Married & $0.89(0.74$ to 1.08$)$ & $0.78(0.50$ to 1.22$)$ & $0.97(0.75$ to 1.26$)$ & $0.94(0.67$ to 1.31$)$ \\
\hline Live with a parent & $0.93(0.79$ to 1.10$)$ & $0.96(0.70$ to 1.30$)$ & 0.95 (0.71 to 1.27$)$ & $0.86(0.34$ to 2.16$)$ \\
\hline Live with a child & 1.07 (0.91 to 1.26$)$ & $1.13(0.68$ to 1.88$)$ & $1.10(0.88$ to 1.36$)$ & $1.10(0.76$ to 1.60$)$ \\
\hline Prefecture fixed effects & Yes & Yes & Yes & Yes \\
\hline Hosmer-Lemeshow $P$ value & .997 & .450 & .188 & .161 \\
\hline
\end{tabular}

$* P<.05$.

$* * P<.01$

$* * * P<.001$.

\section{Discussion}

\section{Principal Results}

Using a unique survey in Japan, we found that individuals' uptake of COVID-19 contact tracing apps is determined by their agreeableness, attachment to the community, concern about health risks, concern about social risks, and trust in the national government; however, key determinants differ across generations. For cohorts aged between 20 and 39 years, attachment to the community plays a pivotal role, while concerns about their health, the social impact of COVID-19, and trust in the national government are less relevant. For those aged between 40 and 59 years, an agreeable personality, concern about the social impact of COVID-19, and trust in the national government facilitate uptake. Finally, adults over 60 years of age, having greater concern about the health impact of COVID-19, were more likely to download the app.

Providing rigorous evidence to explain the causes of heterogeneous patterns across generations is a challenge. That said, we speculate that downloading the contact tracing app may offer fewer benefits for younger age groups, who are less likely to become severely ill from COVID-19. Hence, they may see it primarily as prosocial behavior, making strong attachment to the community at local and national levels essential for uptake. Furthermore, we found that trust in government did not influence uptake decisions for younger age groups, likely because they already use many mobile apps, including those for web-based games, shopping, and social media, and thus may be less concerned about online privacy and security. In contrast, health care is the largest issue among older adults, and those who were concerned about their health risk used the app, regardless of their trust in government or prosociality. Finally, middle-age respondents were more likely than those in other age groups to live in a large household with children and parents; therefore, they may have been more concerned about security and privacy issues. Hence, their uptake decision relied mostly on whether they find the government trustworthy or not. If they did not trust the government, even individuals who were prosocial and concerned about health risks were less likely to install COCOA.

\section{Limitations}

A potential limitation of this study was sample selection. We used a web-based survey because the situation created by the spread of COVID-19 made it difficult to conduct either paper-and-pencil postal surveys or in-person surveys in a timely manner. As a result, those with poor internet literacy were excluded from our sample. However, we believe that this issue is unlikely to be severe. Since this study examines the uptake decision with respect to a mobile app, those who do not have access to the internet or smartphones are less relevant to our analysis. Furthermore, the characteristics of our respondents were comparable with those of smartphone owners in Japan.

\section{Comparison With Prior Work}

This study makes 4 contributions to the literature. First, the importance of prosociality and community in controlling the COVID-19 pandemic has been frequently discussed, and previous studies $[55,56]$ have demonstrated the association of 
prosociality and community with individuals' social-distancing behavior and mental health. In general, the literature on public health and disaster research also supports the roles of community in encouraging protective behavior [14,57]. However, the association between prosociality and uptake of COVID-19 contact tracing apps is largely unexplored, with the exception of 2 studies that have examined the role of prosocial personality traits and attitudes [7,58]; attachment to the community is less well understood. This is problematic because, unlike personality traits, feelings of attachment may easily change over time in response to changes in one's living conditions [59]. Our findings suggest that, if social-distancing requirements during the pandemic weaken community attachment, then this could have a negative effect on uptake decisions, especially among young people.

Second, this study is the first to examine differences in app uptake across generations. Differences across age groups suggest that conducting an empirical analysis without taking generational heterogeneity into consideration (as previous studies have neglected to take into consideration) leads to misunderstandings about individuals' behavioral responses to the COVID-19 pandemic. Risk and symptomatic severity of infections vary across age groups. Specifically, young generations account for a large proportion of confirmed cases in Japan, and it is relevant for policymakers to contain the spread of infection among young generations even though they are less likely to become severely ill.

Third, previous studies $[9,11,53]$ on contact tracing apps mainly used survey data collected before the release of the apps and examined the willingness to install a hypothetical app. While their arguments were insightful, the actual adoption rates were remarkably lower than what had been predicted. This suggests the importance of further research to analyze actual uptake decisions, as performed in our study and in a few others $[7,8,60]$.

Fourth, this study contributed to the literature on disaster resilience. Existing scholarship emphasizes the importance of strong communities and institutions, along with the development of physical infrastructure [61,62]. However, whether these factors play complementary or substitute roles remains unsubstantiated. This study provides rigorous evidence that attachment to one's community boosts the effectiveness of contact tracing technology.

\section{Conclusion}

Given these arguments, policymakers should implement and advance different interventions for each generation to increase the adoption rate of contact tracing apps. These strategies are relevant, not only to the COVID-19 pandemic, but also, to possible future pandemics in which decentralized contract-tracing may be relevant to the mitigation of human, social, and economic suffering. Specifically, older adults demonstrate higher concerns about health risks than younger individuals; such concerns are the primary motivation for uptake by older adults. Therefore, a promising approach is to inform them about the health benefit from the apps, such as receiving medical treatment sooner. For middle-age persons, it is important to mitigate their concerns about security and privacy issues. Finally, uptake by young persons is determined by their attachment to the community; however, interventions to inform them that the app prevents users from spreading the infection may not be effective, because on average, young adults do not feel as attached to their community as older adults. Instead, it is important to maintain and raise their feeling of community attachment at the local and national levels. This may be challenging because social-distancing requirements during the pandemic have reduced face-to-face social interactions among community members. However, the use of social media and other web-based network tools may compensate for the lack of such opportunities. A study [63] of American university students showed that communication through social media (Facebook) helped young people maintain relationships with those who were physically at a distance, such as high school friends from their hometowns. Some Japanese municipalities have introduced web-based events to facilitate social interactions among the young generation during the COVID-19 pandemic, such as coming-of-age ceremonies, childcare workshops for young parents, and festivals or activities for families with young children [64]. That said, these approaches also have drawbacks. First, online or social media communities and online meetings often include only young users, whose health risk is low. Social interactions among such people may not lead to stronger motivations to engage in prosocial behavior for senior persons. Second, it is not evident how long prosociality developed through web-based tools persists.

While these implications are grounded in evidence from Japan, we expect them to be pertinent to other countries. The relevance of risk perception and trust in government to uptake decisions for contact tracing apps have been widely recognized in many countries [7-9,11]. In addition, our argument about the role of prosociality is applicable to any country where app uptake depends on voluntary, individual decisions alone. Nonetheless, we should be cautious about the generalizability of implementing different interventions across generations, because there is no comparable evidence from other countries on generational differences in uptake decisions. The key determinants of uptake among young and older generations may depend on the demographic, cultural, and socioeconomic characteristics of each country. Additional studies in other countries are required to establish which combination of policy interventions is most effective for each generation.

\section{Acknowledgments}

This manuscript was prepared with support from the Institute of Social Science (University of Tokyo) and its institute-wide joint research project (Methodology of Social Sciences: How to Measure Phenomena and Values). This work was supported by Japan Society for the Promotion of Science Kakenhi grants (20K01689, 18K01501, and 17H02478) and the Institute of Social Science Group Joint Research Project grant (Social Sciences of Digitalization). 


\section{Conflicts of Interest}

None declared.

\section{Multimedia Appendix 1}

Supplementary tables.

[DOCX File, 29 KB-Multimedia Appendix 1]

\section{References}

1. Atkeson A. What will be the economic impact of COVID-19 in the US? rough estimates of disease scenarios. National Bureau of Economic Research. 2020 Mar. URL: https://www.nber.org/system/files/working papers/w26867/w26867.pdf [accessed 2021-08-15]

2. Sumner A, Hoy C, Ortiz-Juarez E. Estimates of the Impact of COVID-19 on Global Poverty. United Nations University World Institute for Development Economics Research. 2020. URL: https://www.wider.unu.edu/sites/default/files/Publications/ Working-paper/PDF/wp2020-43.pdf [accessed 2021-08-15]

3. Budd J, Miller BS, Manning EM, Lampos V, Zhuang M, Edelstein M, et al. Digital technologies in the public-health response to COVID-19. Nat Med 2020 Aug 07;26(8):1183-1192. [doi: 10.1038/s41591-020-1011-4] [Medline: 32770165]

4. Johnson B. The COVID tracing tracker: what's happening in coronavirus apps around the world. MIT Technology Review. 2020 Dec 16. URL: https://www.technologyreview.com/2020/12/16/1014878/covid-tracing-tracker/ [accessed 2021-05-20]

5. Ferretti L, Wymant C, Kendall M, Zhao L, Nurtay A, Abeler-Dörner L, et al. Quantifying SARS-CoV-2 transmission suggests epidemic control with digital contact tracing. Science 2020 May 08;368(6491):eabb6936 [FREE Full text] [doi: 10.1126/science.abb6936] [Medline: $\underline{\text { 32234805] }}$

6. Hinch R, Probert W, Nurtay A, Kendall M, Wymant C, Hall M, et al. Effective configurations of a digital contact tracing app: a report to NHSX. Semantic Scholar. 2020. URL: https://cdn.theconversation.com/static files/files/1009/ Report - Effective App Configurations.pdf?1587531217 [accessed 2021-05-20]

7. Munzert S, Selb P, Gohdes A, Stoetzer LF, Lowe W. Tracking and promoting the usage of a COVID-19 contact tracing app. Nat Hum Behav 2021 Feb 21;5(2):247-255. [doi: 10.1038/s41562-020-01044-x] [Medline: 33479505]

8. von Wyl V, Höglinger M, Sieber C, Kaufmann M, Moser A, Serra-Burriel M, et al. Drivers of acceptance of COVID-19 proximity tracing apps in Switzerland: panel survey analysis. JMIR Public Health Surveill 2021 Jan 06;7(1):e25701 [FREE Full text] [doi: 10.2196/25701] [Medline: 33326411]

9. Altmann S, Milsom L, Zillessen H, Blasone R, Gerdon F, Bach R, et al. Acceptability of app-based contact tracing for COVID-19: cross-country survey study. JMIR Mhealth Uhealth 2020 Aug 28;8(8):e19857 [FREE Full text] [doi: 10.2196/19857] [Medline: $\underline{32759102]}$

10. Walrave M, Waeterloos C, Ponnet K. Adoption of a contact tracing app for containing COVID-19: a health belief model approach. JMIR Public Health Surveill 2020 Sep 01;6(3):e20572 [FREE Full text] [doi: 10.2196/20572] [Medline: 32755882]

11. Jonker M, de Bekker-Grob E, Veldwijk J, Goossens L, Bour S, Rutten-Van Mölken M. COVID-19 contact tracing apps: predicted uptake in the Netherlands based on a discrete choice experiment. JMIR Mhealth Uhealth 2020 Oct 9;8(10):e20741. [doi: $10.2196 / 20741]$

12. Piliavin A, Dovidio F, Gaertner L, Clark D. Emergency Intervention. New York: Academic Press; 1981.

13. Mazza M, Marano G, Lai C, Janiri L, Sani G. Danger in danger: interpersonal violence during COVID-19 quarantine. Psychiatry Res 2020 Apr 30;289:113046. [doi: 10.1016/j.psychres.2020.113046] [Medline: $\underline{33242810}$ ]

14. Aldrich D. Building Resilience: Social Capital in Postdisaster Recovery. Chicago, IL: University of Chicago Press; 2012.

15. COVID-19. Toyo Keizai Online. URL: https://toyokeizai.net/sp/visual/tko/covid19/ [accessed 2021-04-07]

16. Ahmed N, Michelin RA, Xue W, Ruj S, Malaney R, Kanhere SS, et al. A survey of COVID-19 contact tracing apps. IEEE Access 2020;8:134577-134601. [doi: 10.1109/access.2020.3010226]

17. Nakamoto I, Jiang M, Zhang J, Zhuang W, Guo Y, Jin M, et al. Evaluation of the design and implementation of a peer-to-peer COVID-19 contact tracing mobile app (COCOA) in Japan. JMIR Mhealth Uhealth 2020 Dec 01;8(12):e22098 [FREE Full text] [doi: 10.2196/22098] [Medline: 33170801]

18. Contact confirmation application privacy policy. Ministry of Health, Labor and Welfare, Japan. 2020 Dec 15. URL: https:/ /www.mhlw.go.jp/cocoa/privacypolicy english.html [accessed 2021-05-20]

19. COCOA official home page. Ministry of Health, Labor and Welfare, Japan. URL: https://www.mhlw.go.jp/stf/seisakunitsuite/ bunya/cocoa 00138.html [accessed 2021-04-19]

20. Prendergast C. Intrinsic motivation and incentives. American Economic Review 2008 Apr 01;98(2):201-205. [doi: 10.1257/aer.98.2.201]

21. Cerasoli CP, Nicklin JM, Ford MT. Intrinsic motivation and extrinsic incentives jointly predict performance: a 40-year meta-analysis. Psychol Bull 2014 Jul;140(4):980-1008. [doi: 10.1037/a0035661] [Medline: 24491020]

22. Deci EL, Koestner R, Ryan RM. A meta-analytic review of experiments examining the effects of extrinsic rewards on intrinsic motivation. Psychol Bull 1999 Nov;125(6):627-68; discussion 692. [doi: 10.1037/0033-2909.125.6.627] [Medline: 10589297] 
23. Carpenter J, Myers CK. Why volunteer? evidence on the role of altruism, image, and incentives. J Public Econ 2010 Dec;94(11-12):911-920. [doi: 10.1016/j.jpubeco.2010.07.007]

24. Shoji M. Guilt and prosocial behavior: lab-in-the-field evidence from Bangladesh. Econ Dev Cult Change 2021 Feb 17:1 (forthcoming). [doi: 10.1086/713879]

25. Graziano G, Eisenberg N. Agreeableness: a dimension of personality. In: Hogan R, Johnson J, Briggs S, editors. Handbook of Personality Psychology. Cambridge, MA: Academic Press; 1997:795-824.

26. Ashton MC, Paunonen SV, Helmes E, Jackson DN. Kin altruism, reciprocal altruism, and the big five personality factors. Evol Hum Behav 1998 Jul;19(4):243-255. [doi: 10.1016/s1090-5138(98)00009-9]

27. Bursztyn L, Jensen R. Social image and economic behavior in the field: identifying, understanding, and shaping social pressure. Annu Rev Econ 2017 Aug 02;9(1):131-153. [doi: 10.1146/annurev-economics-063016-103625]

28. Shaw CR, McKay HD. Juvenile Delinquency and Urban Areas. Chicago, Illinois: University of Chicago Press; Jan $1943: 681$.

29. Frailing K, Wood-Harper D. Crime and disaster in historical perspective. In: Crime and Criminal Justice in Disaster. Durham NC: Carolina Academic Press; 2010.

30. Shoji M. Religious fractionalisation and crimes in disaster-affected communities: survey evidence from Bangladesh. J Dev Stud 2017 Nov 06;54(10):1891-1911. [doi: 10.1080/00220388.2017.1393521]

31. Kondo A, Shoji M. Peer effects in employment status: evidence from housing lotteries. J Urban Econ 2019 Sep;113:103195. [doi: 10.1016/j.jue.2019.103195]

32. Ben-Ner A, McCall BP, Stephane M, Wang H. Identity and in-group/out-group differentiation in work and giving behaviors: Experimental evidence. J Econ Behav Organ 2009 Oct;72(1):153-170. [doi: 10.1016/j.jebo.2009.05.007]

33. Fershtman C, Gneezy U. Discrimination in a Segmented Society: An Experimental Approach. Q J Econ 2001 Feb 01;116(1):351-377. [doi: 10.1162/003355301556338]

34. Etang A, Fielding D, Knowles S. Does trust extend beyond the village? experimental trust and social distance in Cameroon. Exp Econ 2010 Sep 16;14(1):15-35. [doi: 10.1007/s10683-010-9255-3]

35. Alesina A, La Ferrara E. Participation in Heterogeneous Communities*. Q J Econ 2000 Aug;115(3):847-904. [doi: 10.1162/003355300554935]

36. Proshansky HM, Fabian AK, Kaminoff R. Place-identity: physical world socialization of the self. J Environ Psychol 1983 Mar;3(1):57-83. [doi: 10.1016/s0272-4944(83)80021-8]

37. Kasarda JD, Janowitz M. Community attachment in mass society. Am Sociol Rev 1974 Jun;39(3):328. [doi: 10.2307/2094293]

38. McMillan DW, Chavis DM. Sense of community: a definition and theory. J Community Psychol 1986 Jan;14(1):6-23. [doi: 10.1002/1520-6629(198601)14:1<6::aid-jcop2290140103>3.0.c0;2-i]

39. Brown G, Raymond C. The relationship between place attachment and landscape values: toward mapping place attachment. Appl Geogr 2007 Apr;27(2):89-111. [doi: 10.1016/j.apgeog.2006.11.002]

40. Mesch GS, Manor O. Social ties, environmental perception, and local attachment. Environ Behav 2016 Jul 26;30(4):504-519. [doi: 10.1177/001391659803000405]

41. Gosling SD, Rentfrow PJ, Swann WB. A very brief measure of the big-five personality domains. J Res Pers 2003 Dec;37(6):504-528. [doi: 10.1016/s0092-6566(03)00046-1]

42. Inglehart R, Haerpfer C, Moreno A, Welzel C, Kizilova K, Diez-Medrano J, et al. Round six - country-pooled datafile version. World Values Survey. JD Systems Institute: Madrid; 2014. URL: https://www.worldvaluessurvey.org/ WVSDocumentationWV6.jsp [accessed 2021-08-15]

43. Raymond CM, Brown G, Weber D. The measurement of place attachment: personal, community, and environmental connections. J Environ Psychol 2010 Dec;30(4):422-434. [doi: 10.1016/j.jenvp.2010.08.002]

44. Pitas NAD, Mowen AJ, Powers SL. Person-place relationships, social capital, and health outcomes at a nonprofit community wellness center. J Leis Res 2020 Jun 16;52(2):247-264. [doi: 10.1080/00222216.2020.1776652]

45. Williams DR, Patterson ME, Roggenbuck JW, Watson AE. Beyond the commodity metaphor: examining emotional and symbolic attachment to place. Leis Sci 1992 Jan;14(1):29-46. [doi: 10.1080/01490409209513155]

46. Gustafson P. More cosmopolitan, no less local: the orientations of international travellers. Eur Soc 2009 Feb;11(1):25-47. [doi: $10.1080 / 14616690802209689]$

47. Rogers W, Prentice-Dunn S. Protection motivation theory. In: Handbook of Health Behavior Research 1: Personal and Social Determinants. New York, NY: Plenum Press; 1997:113-132.

48. Shoji M, Cato S, Iida T, Ishida K, Ito A, McElwain K. COVID-19 and social distancing in the absence of legal enforcement: survey evidence from Japan. University Library LMU Munich. 2020. URL: https://mpra.ub.uni-muenchen.de/101968/ [accessed 2021-08-15]

49. Ikeda S, Kato H, Ohtake F, Tsutsui Y. Behavioral Economics of Preferences, Choices, and Happiness. New York NY: Springer; 2016.

50. Iida T. Yūkensha no Risuku Taido to Tōhyōkōdō. Tokyo: Bokutakusha; 2016.

51. Nakamoto I, Jiang M, Zhang J, Zhuang W, Guo Y, Jin M, et al. Evaluation of the design and implementation of a peer-to-peer COVID-19 contact tracing mobile app (COCOA) in Japan. JMIR Mhealth Uhealth 2020 Dec 01;8(12):e22098 [FREE Full text] [doi: 10.2196/22098] [Medline: $\underline{33170801]}$ 
52. Sesshoku Kakunin Apuri Hukyuu Habamu Kabe wo Dou Torinozokuka. August. In: Yomiuri Shimbun. Tokyo: Yomiuri Shimbun; Aug 3, 2020.

53. Guillon M, Kergall P. Attitudes and opinions on quarantine and support for a contact-tracing application in France during the COVID-19 outbreak. Public Health 2020 Nov;188:21-31 [FREE Full text] [doi: 10.1016/j.puhe.2020.08.026] [Medline: 33059232]

54. Communications usage trend survey. Ministry of Internal Affairs and Communications. 2019. URL: https://www.soumu.go.jp/ johotsusintokei/statistics/pdf/HR201900_001.pdf [accessed 2021-06-03]

55. Cato S, Iida T, Ishida K, Ito A, McElwain K, Shoji M. Social distancing as a public good under the COVID-19 pandemic. Public Health 2020 Nov;188:51-53 [FREE Full text] [doi: 10.1016/j.puhe.2020.08.005] [Medline: 33120232]

56. Meagher BR, Cheadle AD. Distant from others, but close to home: the relationship between home attachment and mental health during COVID-19. J Environ Psychol 2020 Dec;72:101516. [doi: 10.1016/j.jenvp.2020.101516]

57. Kawachi I, Subramanian V, Kim D. , ,. In: Social Capital and Health. New York, NY: Springer; 2008.

58. Li T, Cobb C, Yang J, Baviskar S, Agarwal Y, Li B, et al. What makes people install a COVID-19 contact-tracing app? understanding the influence of app design and individual difference on contact-tracing app adoption intention. Pervasive Mob Comput 2021 Aug;75:101439. [doi: 10.1016/j.pmcj.2021.101439]

59. von Wirth T, Grêt-Regamey A, Moser C, Stauffacher M. Exploring the influence of perceived urban change on residents' place attachment. J Environ Psychol 2016 Jun;46:67-82. [doi: 10.1016/j.jenvp.2016.03.001]

60. Saw YE, Tan EY, Liu JS, Liu JC. Predicting public uptake of digital contact tracing during the COVID-19 pandemic: results from a nationwide survey in Singapore. J Med Internet Res 2021 Feb 03;23(2):e24730 [FREE Full text] [doi: 10.2196/24730] [Medline: 33465034]

61. Ainuddin S, Routray JK. Community resilience framework for an earthquake prone area in Baluchistan. Int J Disaster Risk Reduct 2012 Dec;2:25-36. [doi: 10.1016/j.ijdrr.2012.07.003]

62. Cutter SL, Barnes L, Berry M, Burton C, Evans E, Tate E, et al. A place-based model for understanding community resilience to natural disasters. Glob Environ Change 2008 Oct;18(4):598-606. [doi: 10.1016/j.gloenvcha.2008.07.013]

63. Ellison B, Steinfield C, Lampe C. The benefits of Facebook "friends:" social capital and college students' use of online social network sites. J Comput Mediat Commun 2007;12(4):1143-1168. [doi: 10.1111/j.1083-6101.2007.00367.x]

64. Atarashii Chiiki Katsudou Sutairu Jireishuu. Kyoto City Official Website. URL: https://www.city.kyoto.lg.jp/bunshi/page/ 00002683html [accessed 2021-06-03]

\title{
Abbreviations \\ COCOA: COVID-19 Contact Confirming App \\ OR: odds ratio
}

\author{
Edited by L Buis; submitted 26.04.21; peer-reviewed by N Lunt, X Cheng, E Aono; comments to author 19.05.21; revised version \\ received 07.06.21; accepted 23.07.21; published 19.08.21 \\ Please cite as: \\ Shoji $M$, Ito A, Cato S, Iida T, Ishida K, Katsumata H, McElwain KM \\ Prosociality and the Uptake of COVID-19 Contact Tracing Apps: Survey Analysis of Intergenerational Differences in Japan \\ JMIR Mhealth Uhealth 2021;9(8):e29923 \\ URL: https://mhealth.jmir.org/2021/8/e29923 \\ doi: $10.2196 / 29923$ \\ PMID: $\underline{34313601}$
}

CMasahiro Shoji, Asei Ito, Susumu Cato, Takashi Iida, Kenji Ishida, Hiroto Katsumata, Kenneth Mori McElwain. Originally published in JMIR mHealth and uHealth (https://mhealth.jmir.org), 19.08.2021. This is an open-access article distributed under the terms of the Creative Commons Attribution License (https://creativecommons.org/licenses/by/4.0/), which permits unrestricted use, distribution, and reproduction in any medium, provided the original work, first published in JMIR mHealth and uHealth, is properly cited. The complete bibliographic information, a link to the original publication on https://mhealth.jmir.org/, as well as this copyright and license information must be included. 